\title{
University Student's Perception of Jeremiah in New Normal Era: The controversy of Jeremiah's Calling as A Prophet
}

\author{
Herowati sitorus, Rogate Artaida Tiarasi Gultom, Megawati Manullang, Manusiar \\ Hernawati Sitorus, Roy Charly Sipahutar \\ Institut Agama Kristen Negeri Tarutung \\ E-mail address herowatisitorus@gmail.com
}

\begin{abstract}
This article describes how a great prophet, Jeremiah, who was chosen by God, worked among the Israelites who were living in exile. During his ministry, he received a lot of criticism from other prophets; there was a conflict in the news. In writing this article, a constructive theological approach was carried out for students in understanding the differences in the teachings conveyed by Jeremiah and the other prophets. This approach will explain how the content of Jeremiah's teaching is a message of peace that can be received by the Israelites as immigrants in a foreign land. How do students, as newcomers to a new place, adapt to the new context and lifestyle to feel peace?
\end{abstract}

Keywords: Teachings of the Prophet, Controversy, Calling the Prophet, Student Perception

\section{INTRODUCTION}

The understanding of the prophet for the Israelites as a person who was sent was chosen by God to deliver prophecies of salvation and even condemnation of the sins they had committed against God. A prophet is a seer or person who delivers God's voice to His people. The term prophet is found in the Old Testament related to several terms including ra'a (seers), isy Elohim (God's people), prophets (most commonly and widely used in the Old Testament), Bene-nebi (sons of prophets). Jeremiah was one of the prophets who prophesied for the nation of Israel. The author will describe how Jeremiah's prophecy in the Israelite tradition? How was Jeremiah's very strict teaching?

The calling of Jeremiah to be a prophet based on the voice of God who came to him, and confirms him as a prophet who has the authority to deliver the prophecies of God's criticism, raises Jeremiah over the nations and over kingdoms to uproot and tear down, to destroy and tear down, build and plant (Jer. .1: 4-10). This is an example of how the entire person and lifestyle of a prophet is devoted to his task and message. Jeremiah was not permitted to marry and have children as a symbol of the desolation of the land, which was under judgment.

\section{RESEARCH METHODOLOGY}

A constructive theological study of the prophet Jeremiah's preaching. Writing articles uses qualitative research methods, namely research sourced from textbooks, articles, and other written materials. The writing of this article uses a critical historical exegesis interpretation method based on library research. The author interviewed students on campus to gain perceptions/understanding of the teachings of the 
Proceeding on International Conference of Education in the New Normal Era (ICEIAKN)

Vol. 1 (1), 63-68

University Student's Perception of Jeremiah in New Normal Era: The controversy of Jeremiah's Calling as A Prophet

Herowati sitorus, M.Th, Rogate Artaida Tiarasi Gultom, M.th, Dra. Megawati Manullang, M.Th, Manusiar Hernawati Sitorus, M.Th, Roy Charly Sipahutar, M.Th

prophet Jeremiah. Interviews were conducted with final semester students because they had received courses related to the introduction of the prophet Jeremiah.

\section{FINDING AND DISCUSSION}

Actually, Jeremiah didn't want to be a prophet. For him, the task of prophethood must have brought chaos to himself, whereas he himself desired peace. Von Rad also saw that Jeremiah's rejection was initially a very hard struggle for him, he tried to discuss it with God because Jeremiah felt that the call that was given to him was suffering, but in the end, Jeremiah carried out his prophetic task, delivering God's message to the Israelites ( Jeremiah 15: 12-18). Appearing as a prophet in Jerusalem with a message in the form of a very serious threat to him who always wanted peace. Jeremiah's prophetic utterances early in his ministry were warnings of the imminent military and political calamity of Judah (Jer. 1: 11-16; 4: 5-8; 6: 22-23). Sometimes the prophetic task was so hard for him that he was willing to rebel. Jeremiah felt he did not deserve the assignment because he was young. The author will describe how the prophets and teachings of the prophet Jeremiah.

\section{Jeremiah's Place of Prophethood in Israel's Prophetic Tradition}

Jeremiah was truly called the strong prophet and teacher of his time. What about humans, teachers, students today? Is doing work a vocation or just a profession? Jeremiah's teachings can serve as a model for today's teaching.

Jeremiah prophesied for the nation of Israel during the early days of Josiah's reformation. The historical, social, cultural, economic, and religious backgrounds at the time when the prophet Jeremiah prophesied influenced the style of the prophecies he conveyed to God's people. The political situation at that time was marked by the denomination or power of major empires such as Assyria, Egypt, and others. In turn, the Israelites became a colony of the great nations until they were finally exiled to Babylon in $597 \mathrm{BC}$. The occupation of these great nations over the Israelites was understood by the prophets as punishment for His people who rebelled against God, be it social, political, economic, or religious rebellion. Jeremiah once warned that the Israelites did not need to ask other nations for help. The crisis they experience is the result of their rebellion against God in all dimensions of life. The punishment they received was the result of their sin of rebellion against God. The syncretism was rampant as a result of them under the pressure and influence of the Assyrians and Babylonians, who were beginning to emerge. Therefore, the way out of the crisis they experienced was not to help from other nations but repentance for the sin of rebellion they had committed against God.

Jeremiah worked individually without any royalties. In his ministry as a prophet, he was free to criticize the government system. Even Jeremiah also criticized the prophet Hananya who worked for the interests of the kingdom (professional prophet). Jeremiah criticizes Hananya's shalom and exile prophecies. Jeremiah criticized Hananya's prophecy because it was influenced by the interests of the kingdom-rulers.

Jeremiah's calling as a prophet proves that he is an individual prophet, called directly by God. Jeremiah tried to reject the call to be a prophet, but because God had appointed him to be a prophet from the time he was in his mother's womb, Jeremiah could not possibly reject the call. The calling of the prophet is a very tough task because the prophet must be a pillar of iron and a wall of copper (Jer. 1:18). But God will be with the prophet in his assignment (Jer. 1:18, 19).

Jeremiah addresses his grievances in private / confessions. He was a very sensitive and gentle-hearted prophet. Jeremiah experienced much criticism and suffering because of his assignment and criticism. The task that lies on his back is very difficult to carry out because he has to criticize the government for acting arbitrarily. 
Proceeding on International Conference of Education in the New Normal Era (ICEIAKN)

Vol. 1 (1), 63-68

University Student's Perception of Jeremiah in New Normal Era: The controversy of Jeremiah's Calling as A Prophet

Herowati sitorus, M.Th, Rogate Artaida Tiarasi Gultom, M.th, Dra. Megawati Manullang, M.Th, Manusiar Hernawati Sitorus, M.Th, Roy Charly Sipahutar, M.Th

Jeremiah's life history makes him better known than other prophets in the OT. Jeremiah, son of a Hilkian priest of Abiathar descent, a priest who was driven to Anathoth by Solomon for his involvement in Adonijah's plot to usurp the throne (1 Kings 2:26). Hilkiah's family had been deprived of their right to carry out their priestly office as a result of Josiah's widespread reforms, which abolished the shrine outside Jerusalem. Jeremiah served during the reign of the four kings who reigned from Josiah, Jehoiakim, Jehoiachin to Zedekiah.

\section{The Book of Jeremiah}

The book of Jeremiah is basically organized and combined in a large book section. The book of Jeremiah contains a message of hope. The hope that forms the basis of political chaos and human suffering. The hope at the time of Jeremiah also experienced critical times, the hope for the future, and the restoration (renewal) of Israel. After discussing the book of Jeremiah and especially the message he sent to the exiles in the letter he sent them, we can see a very beautiful message. The message is that they can bring prosperity to the dumpsite because that way, they can also prosper. As complicated and complex as any discussion of the book of Jeremiah, modern readers can understand that there was a plan of God that was fulfilled. God's people were punished for not believing in prophecy, but in the end, they were restored and developed prosperity.

The general purpose of writing the book of Jeremiah was that God called Jeremiah to rebuke the people of Judah for committing various kinds of sins: idolatry (Jer. 2: 5-3: 5), injustice (Jer. 5: 20-31) and abuse of worship (Jer. 7): 8-31). To them, Jeremiah delivered a warning from the LORD in the form of punishment through the Babylonians. They were called to return to the LORD (Jer. 3: 12-13) and change their ways (Jer. 7: 3-7). When they kept stiff neck, the Lord's punishment finally came true (Jer 29: 12). However, God is still true to His covenants. He had a wonderful plan behind all of this (Jer. 29:11) to bring them back from Babylon (Jer. 29:10) and build the city of Jerusalem again (Jer. 30:18). He even promised a new covenant with His people (Jer. 31: 31-34) by placing a descendant of David on the throne (Jer. 33: 15-26) so that the people of Judah would return to God (Jer. 29: 12-14). God's relationship with His people is like a husband and wife relationship that lives in love. The punishment that God gives as proof of God's love for His people. God remains true to His covenants.

The specific purpose of writing the book can be traced to the story of Jeremiah's calling. In this story, the main idea is expressed explicitly, which will appear many times throughout the book: God's sovereignty to bless or punish (Jer. 1:10). The LORD is likened to a person who has the right to mold clay into whatever vessel He wants (Jer. 18: 1-11). All of this has to do with the response of a nation to God (Jer. 18: 6-10). Based on this concept, the people of Judah are reminded to repent and return to God. The kings, especially Jehoiakim and Zedekiah, as well as the prophets of Hananya (Jer. 28) and other leaders, the people in the crowd viewed Jeremiah's prophecies as insulting the government, nation, and religion (Jer. 26). They also submitted to the Babylonians and were banished from the promised land.

It was in this exile that Jeremiah wrote his book to help the people of Judah to reflect on all that had happened. The defeat of Babylon was not the result of God's fault or helplessness before the Babylonian gods. All happened because the people of Judah refused to repent and rely on God. This book also reminds the people in exile about the promise of restoration that was uttered by Jeremiah to comfort the people of Judah in exile that God has the power to change their situation.

It is not only the time of writing of the book, which Jeremiah was when he worked that OT theologians argue, but the content and structure of the Book of Jeremiah also becomes something very interesting to discuss. For example, for Jer. 36, there are theologians who claim that this chapter is the conclusion of the third chapter of the book, but there are also those who maintain that this chapter is the beginning of the fourth part of the Book of Jeremiah. This difference develops against the background of the different perspectives of the readers in understanding the very complex contents of the Book of Jeremiah. 
Proceeding on International Conference of Education in the New Normal Era (ICEIAKN)

Vol. 1 (1), 63-68

University Student's Perception of Jeremiah in New Normal Era: The controversy of Jeremiah's Calling as A Prophet

Herowati sitorus, M.Th, Rogate Artaida Tiarasi Gultom, M.th, Dra. Megawati Manullang, M.Th, Manusiar Hernawati Sitorus, M.Th, Roy Charly Sipahutar, M.Th

Caroll, however, divides it into six parts: (1) Introduction: Jer. 1: 1-19 introduces Jeremiah, his family, the social context and timing of his activities (Jer. 1-3); his office as a prophet to the nations (Jer. 1: 410); two visions (Jer. 1: 11-14); material added later (Jer. 1: 15-16; Jer. 17-19). (2) The first part of the verse and exhortation restated on Judah and Jerusalem (Jer. 2: 1-25: 14). (3) The second part of the prophecy against the nations (Jer. 25: 15-38; Jer. 46-51). (4) The third part is a variety of stories, such as Jeremiah's talk to Zedekiah about King Zedekiah's final fate, promises to the Hebrew slaves that were not kept (Jer. 26-36). (5) The fourth part of Jerusalem's fall and its aftermath (Jer. 37-45). (6) The conclusion describes Zedekiah's death and the fall of the Kajan of Judah, the fall of Jerusalem, and the release of Jehoiakim from prison (Jer. 52: 1-34, cf. 2 Kgs. 24: 18-25: 30). Meanwhile, Thompson divided the book of Jeremiah into three parts, namely (1) Prophecies against Judah and Jerusalem (Jer. 1-25). (2) The book of comfort is the hope of the restoration of Jerusalem (Jer. 30-33). (3) The prophecy concerning Gentiles (Jer. 46-51).

The most important form of poetry is in Jer. 1: 4-10 concerning Jeremiah's calling and commissioning as a prophet to the nations and the two visions shown to Jeremiah (Jer. 1: 1-14). Meanwhile, the form of prose is found in Jer. 1: 15-19, which describes the addition of a second vision and its interpretation as a statement delivered by the King of Judah. There is a connection between Jer. 1: 17-19; and Jer. 6: 27-30; Yer. 15: 20-21 concerning Jeremiah's calling to prophesy and to test the people and God's support for him. Next up, Jer. 27-29 is Jeremiah's direct verse. Jeremiah sends letters from Jerusalem to the elders, priests, prophets, and all the people who have been carried into Babylonian exile by Nebuchadnezzar.

Otto Eissfeldt divides the book of Jeremiah into four major sections. The first part, Jer. 1-26, especially concerning the prophecies against Judah. The second part, Jer. 26-45, regarding the stories about Jeremiah. Part three, Jer. 46-51, prophecies against the foreign nations. The fourth part, Jer. 52, is an addendum quoted from $2 \mathrm{Kgs} .18-25: 21$.

The contradiction between Jeremiah and his contemporaries is seen in Jer. 27-28. At the beginning of Zedekiah's reign, envoys from neighboring countries (Edom, Moab, Ammon, and Tire, and Sidon) came to Jerusalem to make a collective agreement against Babylon. God told Jeremiah to make a yoke (axle) of wood and tie it around his neck while delivering His words in the form of messages to the kings through their respective messengers: "I am the one who made the earth, humans and animals ... And now I am submitting All these lands are in the hands of my servant Nebuchadnezzar, King of Babylon... the nations that submit to the King of Babylon will live "(Jer. 27: 5,6,12). In that same year, the prophet Hananya said, "Thus says the Lord .... I have broken the yoke of the King of Babylon," and he broke the axle that was in Jeremiah's neck. However, the LORD told Jeremiah to deliver His message to the false prophet, "You have broken axles from wood, but I will make axles of iron instead ... In that year you will die" (Jer. 28: 13,16).

The candidness of the prophet Jeremiah spoke of the sins of Judah, the exile of the Israelites to Babylon resulted in the prophet Jeremiah having many enemies. Among them are prophets who feel optimistic about the future but have no reason for it. They joined faiths that proved profoundly influenced by the prophets (Jer. 27: 16-18). The influence of the prophets on the priests is strengthened in Jer. 28: 1-4, where Hananya shows her play before the faiths in the Lord's temple to influence them to her stand. The group of prophets appears to have come very close to the Lord's Temple, an idea reinforced by a letter from Shemaiah in exile to priest Zephaniah in Jerusalem who asked why he did not rebuke Jeremiah for promising a longer exile (Jer. 29: 24-28), while the false prophet prophesied that their exile would be faster.

Priests can rule over the prophets and can denounce them. The debate between Jeremiah and the false prophets is very clear. False prophets deliver messages of peace when there is no peace (Jer. 6: 13-15, $8: 11 ; 14: 13-16 ; 23: 17)$. They were guilty of giving false hope to a nation that was sure to perish because of idolatry. The prophecies conveyed by false prophets are not proven true, so this group of prophets is 
often called false prophets. The priests and prophets together accused Jeremiah of prophesying the destruction of the Lord's Temple, and his life was preserved only by the interference of the elders of the land (Jer. 26: 7-19,24). Through actions in the form of signs, God speaks. However, it was only when the events that Jeremiah prophesied took place that he was proven true.

Jeremiah's judgment before the elders took place at the beginning of Jehoiakim's reign and conflict with the prophet Hananya occurred at the start of Zedekiah's reign. Jeremiah's letter to the exiles also from Zedekiah's reign was written immediately after the exile in $597 \mathrm{BC}$ (the first exile to Babylon).

\section{CONCLUSION AND FURTHER RESEARCH}

Jeremiah's prophetic work wreaked havoc on himself, whereas he himself wanted peace. Jeremiah's bold and courageous teaching enabled him to emerge as a prophet in Jerusalem with messages of threats and condemnation to the government. Jeremiah dared to disobey the false prophets in order to convey the truth from God. Jeremiah always wanted the peace that comes from God. However, he must have the courage to convey a message in the form of criticism so that there is a conflict between him and the false prophets.

Jeremiah's prophetic utterances early in his ministry were warnings of the imminent military and political catastrophe of Judah. Jeremiah was truly called the strong prophet and teacher of his time. Students as prospective teachers should also be courageous and firm in implementing innovation in the face of the new normal.

\section{RESULTS AND DISCUSSION}

The main theme of the prophet's preaching was (1) the unfaithfulness of the Israelites as God's chosen people, (2) God sent prophets to prophesy as a warning against them, (3) Israel rejected the prophet's words, (4) God brought punishment. The message that the prophet sent to the Israelites can be concluded that there was a call to obey the law, just like in the Book of Deuteronomy, there is a commandment for the Israelites to obey the law of Moses and the Sabbath.

There has been much discussion of this category. Bright clearly points out that although there is a stylistic agreement between Jeremiah and Deuteronomy, there are also important differences. He concluded that this was a style in itself and that it became part of prose in the seventh and sixth centuries. 1 Jeremiah was a great prophet who worked under criticism in his context. He emphatically criticized the government and refused to cooperate with other prophets. Students in the context of the new normal should also imitate the firm attitude of the prophet Jeremiah. There is the courage to carry out social criticism of institutions where knowledge is hoarded and the government. If the process of teaching and learning activities runs online, can students say that learning must be firmly supported by the campus and the government by facilitating student needs, such as excellent online library service, online registration, more mature lecturer preparation in teaching, not just assigning lectures? Students should adapt to normal conditions when living under pressure from health, economy, and limited space for the effects of staying at home.

\section{REFERENCES}

Bright, John. The Date of the Prose Sermons of Jeremiah. London: SCM Press, LTD, 1951. 
University Student's Perception of Jeremiah in New Normal Era: The controversy of Jeremiah's Calling as A Prophet

Herowati sitorus, M.Th, Rogate Artaida Tiarasi Gultom, M.th, Dra. Megawati Manullang, M.Th, Manusiar Hernawati Sitorus, M.Th, Roy Charly Sipahutar, M.Th

Clements, R.E. Jeremiah. Atlanta, Georgia: John Knox Press, 1988.

Crenshaw, James L. Makers of the Modern Theological Mind Gerhard Von Rad. Waco, Texas: Word Books Publisher, 1978.

Eissfeldt, Otto. The Old Testament An Introduction: The History of the Formation of the Old Testament. Terj. Peter R. Ackroyd. New York and Evanston: Harper and Row Publishers, 1965.

Koch, Klaus. The Prophets: The Assyrian Periode. Philadelphia: Fortress Press, 1989.

Ludji, Barnabas. Barnabas Ludji, Pemahaman Dasar Perjanjian Lama 2. Bandung: Bina Media Informasi, 2009.

Peter C. Craige, Page H. Kelley, dan Joel F. Drinkard, Jr. Jeremiah 1-25. Texas, Dallas: Word Book Publisher, 1991.

Thompson, J. A. The Book of Jeremiah. Grand Rapids: William B. Eerdmans Publishing Company, 1980.

Thomson, J. G. S. The Word of The Lord in Jeremiah. London: The Tyndale Press, 1959.

Vriezen, Th. C. Agama Israel Kuno. Jakarta: BPK gunung Mulia, 2000. 